\section{Tetracycline sensitivity as a cause of excessive flatus}

There has been increased interest in the problem of excessive flatus since Levitt $e t a l,{ }^{1}$ analysed the flatus of a patient and found the content of $\mathrm{H}_{2}$ and $\mathrm{CO}_{2}$ too high to be accounted for by aerophagy. In their patient some improvement followed restriction of dietary lactose, but the cause of the condition was not identified. I report a case in which sensitisation to a water-soluble metabolite of tetracycline caused a similar syndrome.

\section{Case report}

The patient, in her 30s, started to complain of excessive flatus with alternating diarrhoea and constipation 11 years ago, and was treated symptomatically after a barium enema had disclosed no abnormality. The symptom increased over the next two years and were unaffected by any of the standard diets tried. Symptoms seemed worse after eating pork and chicken.

When all food products from pigs and chickens were avoided because of the known use of antibiotics (mainly penicillin and tetracycline) in the foodstuffs of both species for growth promotion, the patient became virtually symptom free. Since then she has suffered an identical syndrome two days after starting treatment with tetracycline, but has been treated with penicillin without ill effect.

In 1971 Britain barred the addition of therapeutically useful antibiotics to food-stuffs for growth promotion, ${ }^{23}$ but they may still be used under veterinary supervision for therapeutic purposes. Infections are frequent under intensive-rearing systems. In Denmark the sale of eggs, milk, or the carcases of tetracycline-treated animals for human consumption is banned for 30 days after the end of treatment, ${ }^{45}$ but no such ban operates in Britain.

The table shows the frequency with which animal products from Britain before and after the 1971 ban and from Denmark during 1976 caused the syndrome. Symptoms have been caused by very small quantities-for example, a tenth of an egg-but the patient can keep symptom-free in Britain with care, and remained so while eating freely in Denmark.

\section{Comment}

It seems certain that the syndrome was caused by a water-soluble metabolite of tetracycline, formed in the animal, passed into eggs and milk, and normally eliminated within 30 days. The metabolite was made by the patient within two days of taking tetracycline by mouth The mechanism is probably one of sensitisation since there is no intolerance to the basic foods. The food responsible is innocuous to normal people, and the patient has a history of hayfever, migraine, and psoriasis with occasional polyarthritis, and a low serum IgA (78 $\mathrm{IU} / \mathrm{ml}$ ) of familial origin. Her sister, also with a low serum IgA $(60$ $\mathrm{IU} / \mathrm{ml})$, had a similar syndrome from acquired gluten sensitivity and an aunt (now dead) had one from an undiscovered cause.

There is no evidence as to whether the original sensitisation was acquired from food or from previous tetracycline treatment: in either case it could be one of a family of sensitisations if other antibiotics give rise in animals to metabolites with similar properties. Sensitisation to a primary constituent of food is relatively easy to detect, but sensitisation to an intermittent food contaminant is more elusive, and should perhaps be suspected in other cases of unexplained flatulence.

${ }^{1}$ Levitt, M D, et al, New England fournal of Medicine, 1976, 295, 260.

2 Veterinary Record, $1971, \mathbf{8 8}, 218$

3 Veterinary Record, 1976, 98, 263.

4 Proclamation of the Danish Ministry of Agriculture, 25 August 1972.

5 Circular issued by the Danish Veterinary Directorate, 25 September 1972.

(Accepted 5 fuly, 1977)

Department of Immunology, The General Infirmary, Leeds

HONOR M ANTHONY, MB, CHB, lecturer, University of Leeds

\section{Le Dantec virus infection in a patient who had not been to West Africa}

Le Dantec virus was first isolated in 1965 at the Institute Pasteur in Senegal. ${ }^{1}$ A 10 -year-old girl had fever and hepatosplenomegaly. Since that time the virus has not been known outside West Africa. Our patient had not been to West Africa, but had been bitten by an insect while unloading a ship that had come from Nigeria and had called at other ports along the West African coast. The case raises the problem of containment of viral infections in the face of increasing international travel, and it also suggests that this virus, like others, may occasionally damage basal ganglia in the brain.

\section{Case report}

When investigated in 1976, the patient, a docker, was 47 . He had not been out of Britain except when in the army from 1948 to 1949 when he had visited Cyprus, Sudan, Eritrea, and Egypt. Since 1949 he had lived in South Wales.

In 1969, while unloading peanuts from a ship that had come from Nigeria, he was bitten by an insect. The bite was on the left lower quadrant of the abdomen, which had been exposed while the patient worked in the ship's hold. He recalled the bite as having caused a stinging pain at the time, but he had not seen the insect. Four days later a red indurated wheal developed at the site of the bite. At that time he felt ill and had fever and headache. He was admitted to hospital, and there became delirious and while in this state jumped out of a hospital window. He remained in hospital for six weeks and four years later developed stiffness of the right arm and hand. After a further two years a tremor of the right hand developed. He was investigated neurologically and Parkinson's disease was diagnosed. From that time he was treated with carbidopa and levodopa (Sinemet). In 1976 he was referred to the Hospital for Tropical Diseases for an opinion as to whether the Parkinsonism could in any way be related to the insect bite received six years earlier.

Investigations for a wide variety of tropically acquired non-viral infections

Frequency of flatulence syndrome after ingesting animal food products from different sources

\begin{tabular}{|c|c|c|c|c|c|}
\hline \multirow[t]{2}{*}{ Species } & \multirow[t]{2}{*}{ Product } & \multirow[t]{2}{*}{ Source } & \multicolumn{3}{|c|}{ Country and date of origin } \\
\hline & & & Britain pre-1971 & Britain post- 1972 & Denmark (1976) \\
\hline Chicken & $\begin{array}{l}\text { Meat } \\
\text { Stock } \\
\text { Eggs }\end{array}$ & $\begin{array}{l}\text { General } \\
\text { Free range } \\
\text { Nature Food* }\end{array}$ & $\begin{array}{l}\text { Frequent } \\
\text { Frequent } \\
\text { None }\end{array}$ & $\begin{array}{l}\text { Frequent } \\
\text { None } \\
\text { None }\end{array}$ & None \\
\hline Sheep & $\begin{array}{l}\text { Bacon } \\
\text { Pork } \\
\text { Pork Products } \\
\text { Stock } \\
\text { Lard } \\
\text { Lamb } \\
\text { Stock }\end{array}$ & $\begin{array}{l}\text { General } \\
\text { Specialt } \\
\text { General } \\
\text { General }\end{array}$ & $\begin{array}{l}\text { Frequent } \\
\text { None } \\
\text { None }\end{array}$ & $\begin{array}{l}\text { Frequent } \\
\text { None } \\
\text { None } \\
\text { None }\end{array}$ & $\begin{array}{l}\text { None } \\
\text { None } \\
\text { None }\end{array}$ \\
\hline Bovine & $\begin{array}{l}\text { Beef } \\
\text { Stock } \\
\text { Milk } \\
\text { Cheese }\end{array}$ & $\begin{array}{l}\text { General } \\
\text { Bulked }+ \\
\text { Limited herd } \\
\text { General }\end{array}$ & $\begin{array}{c}\text { None } \\
\text { Intermittent } \\
\text { Rarely } \\
\text { Occasional }\end{array}$ & $\begin{array}{c}\text { None } \\
\text { Intermittent } \\
\text { Rarely } \\
\text { Occasional }\end{array}$ & $\begin{array}{l}\text { None } \\
\text { None } \\
\text { None } \\
\text { None }\end{array}$ \\
\hline
\end{tabular}

* Guaranteed fed without additives.

† Kown not to have been treated with tetracycline.

Mild syndrome presumably because of the inclusion of milk from cows treated for mastitis.
Veal has been avoided since the diet was started. 
including those that could have been transmitted by the bite gave negative results. These investigations included a complement fixation test for $Q$ fever, malarial fluorescent antibody tests, schistosomal and filarial complement fixation tests, the rapid plasma reagin test and Treponema pallidum haemagglutination test, and a search of blood for trypanosomes. Serum was then examined for an extended range of antibodies to West African viruses (ETWB). Antibodies against Le Dantec virus were found in significant titre $(1 / 16)$. No other viral antibodies were detected.

\section{Comment}

The question of a causal relationship between the insect bite, the infection, and the subsequent Parkinsonism must remain problematic, but there can be little doubt that the febrile illness after the bite occurred when the Le Dantec virus infection was acquired, for the patient had never been to West Africa and had had no other incident so far as he could recall during which he had been bitten while on a ship that had been to West Africa. Many viruses can cause encephalitis, and involvement of the basal ganglia is well recognised in certain viral infections, particularly those with Japanese $B, S t$ Louis, and Murray Valley viruses. It is particularly notable, however, that in the International Catalogue of Arboviruses ${ }^{1}$ Le Dantec virus, on being inoculated into suckling mice, is reported to have produced "severe lesions of encephalitis with important destruction of the neurones of the cerebrum (cortex, thalamus, hypothalamus) less acute in the spinal cord. Perivascular cuffing with mononuclear cells. No myositis." In view of this there was probably a causal relationship between the bite with the infection it conveyed and the subsequent development of Parkinsonism.

The case is notable in focusing attention on the need for vigilance in containing viral infections that could be transmitted by insects carried on transport arriving from Africa. Secondly, it provides suggestive information that Le Dantec virus, like certain other viruses, is capable of damaging the basal ganglia of the, brain.

1 International Catalogue of Arboviruses, ed T O Berge, 2nd edn, p 426. US Department of Health, Education and Welfare, Washington, 1975.

(Accepted 10 August 1977)

Hospital for Tropical Diseases, London NW1 OPE

A W WOODRUFF, MD, FRCP, physician and director, medical unit V E ANSDELL, MB, MRCP, registrar, medical unit

Microbiological Research Establishment, Porton, Salisbury SP4 oJG, Wilts

E T W BOWEN, MIBIOL, FIMLs, head of special pathogens unit

\section{Cardiac arrhythmia after mushroom ingestion}

Mushroom poisoning is relatively uncommon in Britain. Ingestion of the bulb agarics with their lethal "amanita toxins" account for most of the reported deaths but serious reactions may occur with other species, which contain a variety of toxins. ${ }^{1} \mathrm{We}$ describe here the reaction that may follow ingestion of the edible black-spored mushroom Coprinus atramentarius (inky caps) and alcohol.

\section{Case report}

A 37-year-old man became ill after eating wild mushrooms which he and his wife had picked, fried, and eaten on the same day. Two hours after the meal the patient drank three pints of beer and almost immediately felt unwell. His face flushed, a blotchy red rash appeared over the upper half of his body, and his hands and face swelled. He became breathless, sweated profusely, and was nauseated. During the three hours in which the reaction was severe he vomited six times.

The medical history was unremarkable and he had never complained of palpitations. He had not taken any drugs. There was no family history of heart disease or thyrotoxicosis.

On admission his face was flushed and there was peripheral vasodilatation, but the swelling of his face and hands had settled. His temperature was
$37.5 \mathrm{C}$. He had an irregular pulse with a tachycardia of 120 beats $/ \mathrm{min}$. Blood pressure was $110 / 80 \mathrm{~mm} \mathrm{Hg}$. The heart sounds were normal with no audible cardiac murmurs. The remainder of the examination was normal. The admission electrocardiogram (ECG) showed sinus tachycardia with frequent supraventricular ectopic beats.

Twelve hours later the patient felt better but he was in atrial fibrillation with an apex beat of 150 beats/min. His ECG was monitored and he remained in atrial fibrillation for 60 hours before spontaneously reverting to sinus rhythm. The arrhythmias did not recur.

Full blood count; chest radiographs; and serum electrolyte, cardiac enzyme, and protein-bound iodine concentrations were normal. Serial ECGs confirmed the arrhythmias but were otherwise non-specific.

The patient's wife ate the same mushrooms without drinking alcohol and remained well. The mushrooms were identified as Coprinus atramentarius.

\section{Comment}

Toxic reactions after ingesting Coprinus atramentarius are uncommon. Features of the reaction which have been reported include flushing, swelling and rash of the face and hands, tachycardia, hypotension, dyspnoea, nausea, vomiting, and shock. While these effects are unpleasant, recovery, even from severe reactions, usually occurs spontaneously within 24 hours without complications. ${ }^{2}$

The reaction occurs only when alcohol is taken with or up to 24 hours after ingesting cooked mushrooms. ${ }^{1}$ Its intensity is directly related to the quantity of mushrooms and alcohol consumed and the time interval between the two events.

The effects are similar to those that occur when a patient taking disulfiram drinks alcohol. Simandl and Franc ${ }^{3}$ have reported isolating tetraethylthiuramdisulfide (disulfiram) from Coprinus atramentarius, although this has not been confirmed.

Markham has observed reversible ECG changes in most patients during controlled reactions, ${ }^{4}$ while cardiac arrhythmias and myocardial infarctions have been described with toxic interactions ${ }^{5}$ between disulfiram and alcohol.

Because of the similarity between the two reactions cardiac dysfunction may be expected to occur after the alcohol-mushroom reaction, but it has not been reported previously. In our patient the arrhythmias occurred during and for a short time after the reaction and were unlikely to have been coincidental. In a healthy man the effects were self-limiting but in patients with cardiovascular disease the consequences may be more serious. If several hours lapse between the ingestion of the mushrooms and consumption of alcohol the connection between them may not be recognised and a possible cause of cardiac abnormality may be missed.

We thank Mr Thomas Boam, chief technician, Department of Botany, Sheffield University, for his advice.

${ }^{1}$ Buck, R W, New England fournal of Medicine, 1961, 265, 681.

2 Reynolds, W A, and Lowe, F M, New England fournal of Medicine, 1965, 272, 630 .

3 Simandl, J, and Franc, J, Chemike Listy, 1956, 50, 1862.

${ }^{4}$ Markham, J D, and Hoff, E C, fournal of the American Medical Association, 1953, 152, 1597.

${ }^{5}$ Macklim, E A, et al, New England fournal of Medicine, 1951, 146, 1377.

(Accepted 15 fune 1977)

Medical Unit, Northern General Hospital, Sheffield

$M$ J CALEY, MB, CHB, senior house officer

R A CLARK, BSC, MRCP, consultant physician

\section{Male dyspareunia due to short frenulum: an indication for adult circumcision}

The main indications for adult circumcision are a prepuce that cannot be freely retracted behind the glans, fibrosis of the prepucial orifice, recurrent dermatitis of the prepuce, persistent or recurrent balanoprosthesis, paraphimosis, or suspected carcinoma of the penis. Patients are also referred because of inadequate hygiene and because 